\title{
RECENT CHANGES AND CURRENT GAPS IN UKRAINIAN COMPETITION LAW
}

\author{
Student, Paata Phutkaradze \\ Institute of International Relations \\ Taras Shevchenko National University
}

DOI: https://doi.org/10.31435/rsglobal_sr/31012020/6869

\section{ARTICLE INFO}

Received 12 November 2019

Accepted 18 January 2020

Published 31 January 2020

\section{KEYWORDS}

Competition law of Ukraine, Anti-Monopoly Committee of Ukraine, key challenges in Ukrainian Competition law.

\begin{abstract}
Competition law plays an enormous role for development of the economy of Ukraine. Association Agreement signed with the European Union pushed Ukrainian Competition Authority to move forward and fight against anticompetitive agreements. Anti-Monopoly committee of Ukraine has quite sufficient experience in investigation and fighting against cartel agreements. Despite the fact that Ukrainian government gives all efforts for creating free and undistorted competition on the market and tries to maintain market without any restrictive agreements, there are many challenges and gaps to be improved. This paper points out authority and competence of AMCU, recent changes and current gaps in Ukrainian competition law.
\end{abstract}

Citation: Paata Phutkaradze. (2020) Recent Changes and Current Gaps in Ukrainian Competition Law. Science Review. 1(28). doi: 10.31435/rsglobal_sr/31012020/6869

Copyright: (C) 2020 Paata Phutkaradze. This is an open-access article distributed under the terms of the Creative Commons Attribution License (CC BY). The use, distribution or reproduction in other forums is permitted, provided the original author(s) or licensor are credited and that the original publication in this journal is cited, in accordance with accepted academic practice. No use, distribution or reproduction is permitted which does not comply with these terms.

Introduction. A key reform which was made was strengthening of the Antimonopoly Committee of Ukraine (AMCU). The strengthening of AMCU was also prompted by the signing of the EU-Ukraine Association Agreement in 2014 [1], which sought to promote economic and political ties between the two partners. Essentially, the agreement meant that Ukraine had to open up to foreign investment and competition while also being allowed access to the vast European market. In this respect, there was need for Ukraine authorities to create a positive business environment which allowed easy entry of new businesses into its market while dismantling the barriers caused by cartels. Countries, which has signed Association Agreement with European Union has taken obligation to harmonize the competition law and regulations with the EU standards. Ukraine Competition Authority has been trying to fight against cartel agreements since establishment. Despite the immense legislative powers given to AMCU and work, we can see current gaps in Ukrainian competition law.

Development and Current Situation. There have been various legislative changes implemented in Ukraine to prevent cartel activity and monopolization before they happen. The laws help to limit conflicts associated with unethical businesses practices, which firms may engage. A key legislative reform which has been implemented in Ukraine is the merger control legislation. In article 255 (6) of the association agreement between the EU and Ukraine,[2] the emphasis is placed on competition authority publishing principles of horizontal mergers to ensure fair competition in the market. In this regard, AMCU is mandated to investigate proposed mergers and make decisions on whether to grant or refuse clearance for mergers. The AMCU can only grant mergers if they do not lead to restriction of competition or monopolization within the Ukrainian market.[3] Usually, the refusal of AMCU to approve a merger can be overruled by the Cabinet of Ministers of Ukraine (CMU) in certain instances. Specifically, CMU can still permit a merger if the positive effects on the public interests exceed the negative effects on competition unless the restriction undermines the market economy system. However, AMCU is only allowed to take 
action regarding mergers within 5 years after the announcement of a merger. [3] Additionally, to facilitate the oversight role of AMCU, it is required that parties involved in a merger should notify AMCU about the takeover unless there is a lack of co-operation within the parties so that AMCU can accept the notification sent by one of the parties.

Apart from mergers, the hardcore restrictions which AMCU is expected to regulate by the Ukraine Competition Law include price fixing, bid-rigging, production and distribution restriction, and territorial market sharing. [4, p.17] Usually, the competition laws do not only apply to formal written agreements but also cover the informal ones as well. Apart from the formal written agreements, the AMCU enforces the Competition Law in cases of mutual understandings, gentlemen's agreements, informal verbal agreements, and concerted practices such as parallel behavior. However, there are certain exemptions to the prohibition law regarding both horizontal and vertical agreements as outlined in the Competition Law. Specifically, firms which have less than 5\% of market share are not considered cartels and hence, not targeted by investigations regarding monopolization activity to enable it deal with cases of economic misconduct in Ukraine, there are specific challenges faced by the organization, which undermines its ability to carry out its mandate.

A key challenge which undermines operations of AMCU entails relatively low compensation of its staff. [4, p.23] Usually, investigation of claims regarding economic policies requires staff with sophisticated skills. In this regard, failure to effectively compensate AMCU staff implies that the organization is unable to attract or retain staff with high level of economic and legal expertise. In 2014, AMCU responsibility was expanded to include state aid competencies and public procurement [5]. Although there has been an addition of responsibilities to AMCU, the organization experienced a drop in its allocated budget by UAH 42.4 million from 2014 to 2016 [4, p.23]. Also, existing statistics indicate that staff employed in Antimonopoly Committee of Ukraine are among one of the lowest paid public workers in the country with an average monthly salary of EUR 176.9.

Apart from low pay, the antimonopoly committee staff has suffered from a significant exit of staff in recent years. The departure of qualified staff particularly due to insufficient salary has been detrimental to AMCU since it cannot retain the best talent.

Currently, the Ukrainian law concerning violation of competition laws explain that commercial courts can only be involved after appeal by parties who are dissatisfied by AMCU rulings. However, the legislation does not provide for collaboration between commercial courts and AMCU in instances where disputes are first presented to commercial courts. In this regard, there is need for clear guidelines to be developed on ways in which courts can notify AMCU regarding cases of unfair commercial practices to enable the organization participate as third parties in the proceedings [6, p.15]. Such a strategy is crucial in ensuring consistency in provision of fines and penalties regarding violation of competition laws. In 2014, the Ukraine government initiated the National Competition Plan (NCP) which is a policy framework intended to align Ukraine's system of competition policy with the international best practices. The plan was also developed to integrate and implement various pro-competition reforms such as state aid and procurement, competition neutrality, anti-competition regulations, and natural monopolies [6, p. 16].

The primary role of AMCU is to investigate cases of violation of competition laws and ensure companies which are found guilty are penalized [7, pp.265]. In this regard, it is usually the key role of AMCU to advise other government agencies concerning the scope of competition legislation as well as ways of detecting violation of the laws. Although the advocacy work of AMCU deserves recognition, there is a significant gap concerning building capacity of other government agencies to identify violation of competition laws [6, p. 6]. Besides, in 2014, the EU-Ukraine Association Agreement was signed resulting in the ACMU undertaking several steps to reform Ukraine anticompetitive laws with the international standards. Some of the key steps taken by AMCU include developing stringent regulations on mergers, increasing publicity and transparency of AMCU decisions, and publishing criteria of fines and penalties for violation of various competition laws [6, p. 7]. However, a key area where there is still a gap in legislation entails online trading. Specifically, the Ukrainian laws concerning fair competition do not extensively address cases in which foreign online businesses dominate Ukrainian consumer market leading to monopoly or unfair competition for small and medium businesses in the country.

Conclusions. Ukrainian Competition law has been progressing and harmonizing towards the EU competition law since the conclusion of Association Agreement. Despite the fact that Ukrainian Anti-Monopoly Committee uses all efforts to fight against anticompetitive agreements, there are still more to perform and amend to completely meet the EU standards. 


\section{REFERENCES}

1. Aleksyeyenko, O., and Henyk, S., 2019. Two years of state aid in Ukraine. [Online]. Available: http://competitionlawblog.kluwercompetitionlaw.com/2019/08/02/two-years-of-state-aid-in-ukraine/

2. Association Agreement between the European Union and its Member States: Ukraine

3. Svechkar, I., and Voznyuk, O., 2013. Competition law in Ukraine: Overview. Practical Law. [Online]. Available: https://uk.practicallaw.thomsonreuters.com/4-501-

3514?transitionType=DefaultandcontextData $=($ sc.Default)andfirstPage $=$ trueandbhcp $=1$

4. OECD, 2016. OECD Reviews of Competition Law and Policy: Ukraine 2016 - A Report on the Implementation of Previous Recommendations. OECD

5. Usova, A., Artemenko, A., and Vyshnevska, A., 2019. State aid in Ukraine: Results of the first year of enforcement, and further steps of the regulator. [Online]. Available: http://www.mondaq.com/x/725394/international+trade+investment/State+Aid+In+Ukraine+Results+Of+Th e+First+Year+Of+Enforcement+And+Further+Steps+Of+The+Regulator

6. OECD, 2018. Annual report of competition policy developments in Ukraine - 2017. OECD

7. Smyrnova, K., 2014. Enforcement of competition rules in the association agreement between the EU and Ukraine. Yearbook of Antitrust and Regulatory Studies, 7(10) 